\title{
Common bean seeds quality during storage under treatments with potential repellent of aromatic plants
}

\author{
PACHECO, F.P.1*; NOBREGA, L.H.P.N.'; TONINI, M.1; CRUZ-SILVA, C.T.A. ${ }^{1}$ \\ 1 Universidade Estadual do Oeste do Paraná - UNIOESTE - Programa de Pós-graduação em Engenharia Agrícola, \\ CCET/PGEAGRI, Rua Universitária, 2069 - JD. Universitário, Cep: 85819-110, Cascavel, Paraná, Brasil. *Autor \\ para correspondência: fabiop.pacheco@gmail.com
}

\begin{abstract}
: ndustrial chemicals that control pests in stored seed can cause damage to health by residual effects remaining in the grains. Studies of products with potential insecticide and repellent properties are required to decrease post-harvest losses. Thus, the aim of this study was to evaluate the quality and efficiency of seed treatment in beans stored under the following treatments: dried leaves and crushed laurel (Laurus nobilis L.), rosemary (Rosmarinus officinalis L.) and basil (Ocimum basilicum L.), cinnamon powder (Cinnamomum zeylanicum Breyn) and ground cloves (Syzygium aromaticum L.) over eight months. An untreated control and a treatment with diatomaceous earth were used to compare the results. At the beginning and at 30 days, percentages of normal and abnormal seedlings as well as seeds that did not germinate, mass of onehundred seeds, water content and infested seeds were analyzed. At 210 and 240 days, free choice arena and repellency testswere conducted. Treatments did not affect germination, mass of 100 seeds or water content; however, all plants tested showed a repellent effect on the bean weevil.
\end{abstract}

Keywords: bean weevil, botanical insecticides, free choice arena.

RESUMO: Qualidade de sementes de feijão carioca armazenado sob tratamentos com plantas aromáticas de potencial repelente. Produtos químicos industriais que controlam pragas de sementes e grãos armazenados podem causar danos à saúde pelo efeito residual que proporcionam. Assim, são necessários estudos de produtos que apresentem repelência e potencial inseticida e reduzam perdas pós-colheita sem causar danos à saúde. Neste contexto, 0 objetivo deste trabalho foi avaliar a qualidade e eficiência do tratamento com plantas aromáticas: folhas desidratadas e moídas de louro (Laurus nobilis), alecrim (Rosmarinus officinalis) e manjericão (Ocimum basilicum L.), canela em pó (Cinnamomum zeylanicum Breyn) e cravo moído (Syzygium aromaticum L.), em sementes de feijão carioca armazenadas durante oito meses. Uma testemunha sem tratamento e outra com terra de diatomáceas foram utilizadas para comparação dos resultados. No início e a cada 30 dias foram realizadas as determinações de plântulas normais, anormais, sementes não germinadas, massa de cem sementes, teor de água e sementes infestadas. Os testes de arena de livre escolha e repelência foram realizados aos 210 e 240 dias. Os tratamentos não influenciaram a germinação, massa de cem sementes, teor de água. Entretanto, todas as plantas testadas apresentaram efeito repelente sobre 0 caruncho do feijão.

Palavras-chave: arena de livre escolha, caruncho do feijão, inseticidas botânicos.

\section{INTRODUCTION}

Brazil is both the largest of beans producer and consumer, with approximately $17.5 \mathrm{~kg}$ year-1 ${ }^{-1}$ er capita. It stands out in national eating habits because of its great importance in the nutritional diet and availability to the Brazilian people (Silva et al., 2011).
Despite the high demand, farmers with large rural area resist to crop beans, because of its fragility and several pests attack during its stage of development and after harvest. Among the pests that damage the bean crop, Zabrotes subfasciatus 
weevil can be highlighted because it is considered the most important pest during beans storage.

Common beans has low yield because of some difficulty on controlling diseases, the high cost of pesticides, low drought tolerance, susceptibility to pests and poor financial situation of small farmers (family farming), which account for over $67 \%$ Brazilian yield (Galbiatti et al., 2011).

Seeds quality support, during storage period, is affected by several factors as water content and temperature when seeds were stored, package and relative humidity of storage environment (Toledo et al , 2009).

The use of plants whose insecticidal activity controls pests in storage is mainly due to the acquiring of insects resistance to organossintetics insecticides, contamination caused by them when in contact with toxic chemicals on food and workers' poisoning that apply pesticide (Estrela et al., 2006).

As a result of residues found in grains with the use of conventional chemicals, and the damage they have caused to the environment, alternative methods have been tested to control weevil (Mazzonetto \& Vendramim, 2003). Thus, the feasibility of using powders and vegetable oils to control stored grain pests may cause effects on insects such as repellency, disorders and mortality.

Some aromatic plants are known for their repellent activity, such as cinnamon and laurel leaf, with slightly bitter taste; basil , used under immersion in water; rosemary, which when cropped in gardens, protects other plants against pests. The clove plant, known by its distinctive aroma, has in its compound eugenol, commonly used as an antimicrobial and antifungal. Aromatic plants may have repellent effect on insects that had been already proven in form of essential oils (Maia \& Parente Júnior, 2008; Guerra et al. ; 2009; Migliorini et al., 2010; Fazolin et al., 2010; Pinto Júnior et al., 2010; Coitinho et al., 2011; Queiroga et al., 2012; Ootani et al., 2013), and also on insects of stored seeds and grains.

Among the essential oils from aromatic plants, basil essential oil has shown insecticidal and repellent properties (Mwangangi \& Mutisya, 2013); rosemary has carminative and disinfectant properties (Mundo-Crivelli et al., 2014), while cinnamon oil presents $96.2 \%$ repellency to Zabrotes subfasciatus in studies by Oliveira \& Vendramin, (1999). Clove plant has anti-inflammatory and wound healing effects, which has, analgesic, and is effective in removing bacteria from the mouth (Costa et al, 2011). The laurel oil has anti-inflammatory properties and showed $74.6 \%$ repellency to $Z$. subfaciatus (Oliveira \& Vendramin, 1999).

The use of insecticidal plants, mainly in powder form, favors small farmers because of their lower cost, ease of use and they do not require skilled personnel, needer affect the environment. In addition, plants can be cropped in the farm, which facilite their use (Mazzonetto \& Vendramin, 2003).

Diatomaceous earth is an inert powder of silica dioxide extracted from fossil deposits of diatomaceous algae. It is registered in the Brazilian Ministry of Agriculture to be used in barley, corn, wheat, beans and rice seeds and grains to control several stored pest (Pinto Júnior et al., 2010).

In this context, this study aimed at evaluating the control and repellent effects of clove, cinnamon, basil, laurel and rosemary plants when compared with diatomaceous powder on physiological quality of common beans seeds during a eight-month storage.

\section{MATERIAL AND METHODS}

This trial was carried out at the Seeds and Plant Evaluation Laboratory, the Center for Exact and Technological Sciences at Western Paraná State University (UNIOESTE), Cascavel city, Brazil.

Seeds of common beans (Phaseolus vulgaris L.) (25 kg) were stored in double paper packaging with $1.2 \mathrm{~kg}$ seeds for each treatment (aromatic plants, diatomaceous powder and control).

Fresh aromatic plants (laurel, rosemary and basil) were dried in an oven with air circulation at $40{ }^{\circ} \mathrm{C}$ for 60 hours. They were crushed, sieved and mixed with common bean seeds in plastic tray. Then, they were placed in paper packaging , where they remained for eight months without replacement of repellents. Cinnamon and cloves, purchased already ground, were only sieved. The amount of each product to be mixed has been previously determined in order to wrap the seeds more evenly (approximately $5 \mathrm{~g} \mathrm{~kg}^{-1}$ ) according to Pacheco et al. (2008).

The common beans seeds were evaluated according to the following tests:

Germination percentage - Each repetition of 50 seeds was sown on paper germitest moistened with distilled water according to Brasil (2009).

Water content - four replications of each treatment with almost $5 \mathrm{~g}$ seeds were placed in aluminum capsules and taken to oven with air circulation at $105^{\circ} \mathrm{C}$ for 24 hours. After this time, the capsules were removed and placed in a desiccator for about 20 minutes. Then, the samples were weighed again and water content was calculated for each replication. The obtained results were expressed in percentage (Brasil , 2009).

Purity percentage - Firtsly, before treating the seeds, eight samples of $100 \mathrm{~g}$ seeds were separated. The impurities and seeds were manually separated in order to obtain the pure seed percentage 
(Brasil, 2009).

One-hundred seed mass - four samples of 100 seeds were taken pure seeds selection randomly. So, the seeds were weighed and the results were expressed in grams per 100 seeds (Brasil , 2009).

Infested seeds - four random samples of each treatment with one hundred seeds, placed in distilled water for 24 hours, were embed in gerboxes. After this period, a cut was made in the axial direction of the seeds to analyze the core deterioration caused by insects (Brasil, 2009).

Arena of free choice - The Zabrotes subfasciatus used in this trial were raised at the lab. Three arenas of free choice were set and $5 \mathrm{~g}$ of seeds were put into plastic capsules for each treatment at 210 and 240 days. They were distributed in a round plastic container and six insects per gram of seeds were placed in its middle (totaling 102 insects per replication of each arena). After 28 days, the insects counting was done according to each capsule.

In order to compare the repellent effect of aromatic plants used in this trial, it was calculated the repellency index (RI), according to Mazzonetto \& Vendramin (2003). The applied equation was: RI $=2 G /(G+P)$, where $G$ is the percentage of insects on the plant test, and $\mathrm{P}$ is the percentage of insects in the control. The RI values ranged from zero to two, and $\mathrm{RI}=1$ neutral plant, $\mathrm{RI}>1$ = attractive plant and $\mathrm{RI}<1$ = repellent plant.

At the beginning and every 30 days, the tests of seeds quality were carried out (Brasil, 2009) during eight months. The experimental design was completely randomized; data were submitted to normality test, analysis of variance and averages were compared by Scott-Knott test at 0.05 probability using SISVAR 5.3 @ software (Ferreira , 2011).

\section{RESULTS AND DISCUSSION}

There were eight replications, and seeds of common beans had initial purity and water content (Table 1) available for storage, which were above $98 \%$ purity and they were classified as $\mathrm{C} 1$, according to Brasil (2005).

TABLE 1. Inicial purity and water content of common beans

\begin{tabular}{cc}
\hline Parameters & $\%$ \\
\hline Pure seed & 98.45 \\
Crashed seed & 0.32 \\
Void grain & 0.23 \\
Other species & 0.88 \\
Other materials & 0.12 \\
Water content & 13.5 \\
\hline
\end{tabular}

The averages of water content on treatments with aromatic plants were not significant in all storage periods (Table 2). According to the results, the final answers of water content values were lower than the ones at the beginning. Probabily, due to the conditions of storage environment.

The treatments with aromatic plants were not significant at 0.05 probability during the whole storage periods (Table 3 ). The treatment with diatomaceous earth had lower averages of normal seedlings in the last four periods of storage.

The treatment averages were significant at $5 \%$ probability to abnormal seedlings at periods 0,90 and 150 storage days (Table 4). In the initial period, the treatment with clove showed $0 \%$ abnormal seedling. Treatment with diatomaceous earth showed higher values of abnormal seedlings in 90 and 150 day period, differing from cinnamon and control treatment, respectively. These results

TABLE 2. Water content of common beans seeds during storage under treatments with potential repellent of aromatic plants

\begin{tabular}{cccccccc}
\hline Treatments & \multicolumn{7}{c}{ Storage period (days) } \\
& $\mathbf{0}$ & $\mathbf{3 0}$ & $\mathbf{6 0}$ & $\mathbf{9 0}$ & $\mathbf{1 2 0}$ & $\mathbf{1 5 0}$ & $\mathbf{1 8 0}$ \\
\hline Control & $13.2 \mathrm{a}$ & $12.7 \mathrm{a}$ & $10.5 \mathrm{a}$ & $11.0 \mathrm{a}$ & $11.7 \mathrm{a}$ & $11.0 \mathrm{a}$ & $11.1 \mathrm{a}$ \\
Rosemary & $13.4 \mathrm{a}$ & $12.4 \mathrm{a}$ & $10.3 \mathrm{a}$ & $11.7 \mathrm{a}$ & $11.9 \mathrm{a}$ & $10.5 \mathrm{a}$ & $10.8 \mathrm{a}$ \\
Cinnamon & $13.5 \mathrm{a}$ & $12.3 \mathrm{a}$ & $10.6 \mathrm{a}$ & $11.4 \mathrm{a}$ & $12.1 \mathrm{a}$ & $10.8 \mathrm{a}$ & $10.7 \mathrm{a}$ \\
Clove & $14.0 \mathrm{a}$ & $12.7 \mathrm{a}$ & $10.8 \mathrm{a}$ & $11.3 \mathrm{a}$ & $11.6 \mathrm{a}$ & $11.6 \mathrm{a}$ & $11.0 \mathrm{a}$ \\
Laurel & $13.4 \mathrm{a}$ & $12.8 \mathrm{a}$ & $10.4 \mathrm{a}$ & $11.4 \mathrm{a}$ & $11.8 \mathrm{a}$ & $11.0 \mathrm{a}$ & $10.7 \mathrm{a}$ \\
Basil & $13.3 \mathrm{a}$ & $12.3 \mathrm{a}$ & $10.8 \mathrm{a}$ & $11.3 \mathrm{a}$ & $11.5 \mathrm{a}$ & $10.8 \mathrm{a}$ & $10.7 \mathrm{a}$ \\
Diatomaceous Earth & $13.9 \mathrm{a}$ & $12.6 \mathrm{a}$ & $10.5 \mathrm{a}$ & $11.1 \mathrm{a}$ & $11.7 \mathrm{a}$ & $11.5 \mathrm{a}$ & $10.8 \mathrm{a}$ \\
\hline Averages & 13.5 & 12.5 & 10.6 & 11.3 & 11.4 & 11.0 & 10.8 \\
CV (\%) & 2.195 & 1.695 & 1.844 & 2.127 & 4.245 & 3.487 & 1.540 \\
\hline
\end{tabular}

Averages followed by the same letter in the column did not differ by the Scott-Knott test (1974) at 0.05 probability. 
TABLE 3. Normal seedlings percentage of common beans during storage under treatments with potential repellent of aromatic plants

\begin{tabular}{cccccccc}
\hline Treatments & \multicolumn{7}{c}{ Storage period (days) } \\
& $\mathbf{0}$ & $\mathbf{3 0}$ & $\mathbf{6 0}$ & $\mathbf{9 0}$ & $\mathbf{1 2 0}$ & $\mathbf{1 5 0}$ & $\mathbf{1 8 0}$ \\
\hline Control & $94 \mathrm{a}$ & $90 \mathrm{a}$ & $88 \mathrm{a}$ & $91 \mathrm{a}$ & $86 \mathrm{a}$ & $93 \mathrm{a}$ & $91 \mathrm{a}$ \\
Rosemary & $93 \mathrm{a}$ & $96 \mathrm{a}$ & $95 \mathrm{a}$ & $91 \mathrm{a}$ & $93 \mathrm{a}$ & $86 \mathrm{a}$ & $94 \mathrm{a}$ \\
Cinnamon & $93 \mathrm{a}$ & $86 \mathrm{a}$ & $92 \mathrm{a}$ & $95 \mathrm{a}$ & $88 \mathrm{a}$ & $91 \mathrm{a}$ & $94 \mathrm{a}$ \\
Clove & $97 \mathrm{a}$ & $90 \mathrm{a}$ & $88 \mathrm{a}$ & $91 \mathrm{a}$ & $92 \mathrm{a}$ & $92 \mathrm{a}$ & $92 \mathrm{a}$ \\
Laurel & $96 \mathrm{a}$ & $90 \mathrm{a}$ & $91 \mathrm{a}$ & $89 \mathrm{a}$ & $94 \mathrm{a}$ & $86 \mathrm{a}$ & $92 \mathrm{a}$ \\
Basil & $95 \mathrm{a}$ & $86 \mathrm{a}$ & $89 \mathrm{a}$ & $92 \mathrm{a}$ & $91 \mathrm{a}$ & $93 \mathrm{a}$ & $92 \mathrm{a}$ \\
Diatomaceous Earth & $94 \mathrm{a}$ & $90 \mathrm{a}$ & $90 \mathrm{a}$ & $87 \mathrm{a}$ & $85 \mathrm{a}$ & $85 \mathrm{a}$ & $86 \mathrm{a}$ \\
\hline
\end{tabular}

Averages followed by the same letter in the column did not differ by the Scott-Knott test (1974) at 0.05 probability. The presented data were obtained from the original observations followed by the letters obtained from the comparison of averages with the transformation in arcsine $\sqrt{ }(x+0.5) / 100$.

differ from the ones reported by Lazzari (2005), which found out no statistical difference among the treatments with diatomaceous earth $\left(1 \mathrm{~g} \mathrm{~kg}^{-1}\right.$ seeds) and the control.

Treatment averages were significant at $5 \%$ probability for nongerminated seeds for only at 120 storage days for rosemary, basil, diatomaceous earth and control treatment (Table 5). It was observed that diatomaceous earth treatment showed higher mortality rates when compared to cinnamon and laurel powders at 120 storage days. The mortality percentages were 77 and $67 \%$ higher than cinnamon and laurel treatments, respectively. In 150 and 180 storage days, diatomaceous earth showed the highest average of nongerminated seed.

The average percentage of infested seeds showed no significant difference among themselves. However, it is clear that the treatments with rosemary, cinnamon, cloves and basil showed a better control of insects over the studied period (Table 6).

The number of dead insects in the capsule with seeds treated in the arena of free choice test, diatomaceous earth showed statistical difference when compare with all treatments including the control. According to these answers, it can be observed that diatomaceous earth showed the highest average mortality of $Z$. subfasciatus mortality in 210 and 240 storage days.

Souza \& Baldin (2009) have studied seeds stored, treated with aromatics plants powders and observed that there was a variation on the number of emerged adults of $Z$. subfasciatus due to oviposition deterrence and possible antibiotic effects of volatilized compounds on larvae. Thus, larvae feeding can be inhibited leading to death. On the other hand, for treatments with diatomaceous earth, it seems that the cause of adult number variation is associated with dehydration of eggs and / or the environment, working against the adult emergence.

According to Pinto Júnior et al. (2010), common beans, when treated with repellents and diatomaceous earth, have still shown some attraction to Z. subfasciatus, different to what happens with other insects. Sitophilus zeamais and S. oryzae are controlled by diatomaceous earth, allowing that just the top and bottom layers of stored grains can be

TABLE 4. Abnormal seedlings percentage of common beans during storage under treatments with potential repellent of aromatic plants

\begin{tabular}{|c|c|c|c|c|c|c|c|}
\hline \multirow{2}{*}{ Treatments } & \multicolumn{7}{|c|}{ Storage period (days) } \\
\hline & 0 & 30 & 60 & 90 & 120 & 150 & 180 \\
\hline Control & $2 \mathrm{~b}$ & $5 \mathrm{a}$ & $7 \mathrm{a}$ & $6 \mathrm{~b}$ & $9 \mathrm{~b}$ & $3 a$ & $6 a$ \\
\hline Rosemary & $3 b$ & $2 \mathrm{a}$ & $3 a$ & $5 a$ & $2 \mathrm{a}$ & $9 \mathrm{~b}$ & $2 \mathrm{a}$ \\
\hline Cinnamon & $5 c$ & $7 \mathrm{a}$ & $6 a$ & $3 a$ & $6 a$ & $6 \mathrm{~b}$ & $2 \mathrm{a}$ \\
\hline Clove & $0 \mathrm{a}$ & $5 a$ & $8 a$ & $7 \mathrm{~b}$ & $4 a$ & $5 a$ & $6 a$ \\
\hline Laurel & $1 \mathrm{a}$ & $5 a$ & $7 a$ & $5 a$ & $3 a$ & $8 \mathrm{~b}$ & $3 a$ \\
\hline Basil & $3 b$ & $7 \mathrm{a}$ & $9 a$ & $4 a$ & $4 a$ & $3 a$ & $5 a$ \\
\hline Diatomaceous Earth & $3 b$ & $5 \mathrm{a}$ & $6 a$ & $11 \mathrm{~b}$ & $10 \mathrm{~b}$ & $11 \mathrm{~b}$ & $8 \mathrm{a}$ \\
\hline
\end{tabular}

Averages followed by the same letter in the column did not differ by the Scott-Knott test (1974) at 0.05 probability. The presented data were obtained from the original observations followed by the letters obtained from the comparison of averages with the transformation in arcsine $\sqrt{ }(x+0.5) / 100$. 
TABLE 5. Nongerminated seeds percentage of common beans during storage under treatments with potential repellent of aromatic plants

\begin{tabular}{|c|c|c|c|c|c|c|c|}
\hline \multirow{2}{*}{ Treatments } & \multicolumn{7}{|c|}{ Storage period (days) } \\
\hline & 0 & 30 & 60 & 90 & 120 & 150 & 180 \\
\hline Control & $4 \mathrm{a}$ & $5 \mathrm{a}$ & $5 a$ & $3 a$ & $5 b$ & $4 a$ & $3 a$ \\
\hline Rosemary & $4 \mathrm{a}$ & $2 a$ & $2 \mathrm{a}$ & $4 \mathrm{a}$ & $5 b$ & $5 a$ & $4 \mathrm{a}$ \\
\hline Cinnamon & $2 \mathrm{a}$ & 7 a & $2 \mathrm{a}$ & $2 a$ & $2 \mathrm{a}$ & $3 a$ & $4 \mathrm{a}$ \\
\hline Clove & $3 a$ & $5 a$ & $4 \mathrm{a}$ & $2 a$ & $4 \mathrm{a}$ & $3 a$ & $2 \mathrm{a}$ \\
\hline Laurel & $3 a$ & $5 a$ & $2 \mathrm{a}$ & $6 a$ & $3 a$ & $4 \mathrm{a}$ & $5 a$ \\
\hline Basil & $2 \mathrm{a}$ & $7 \mathrm{a}$ & $2 \mathrm{a}$ & $4 \mathrm{a}$ & $5 b$ & $4 \mathrm{a}$ & $3 a$ \\
\hline Diatomaceous Earth & $3 a$ & $5 a$ & $4 a$ & $2 a$ & $9 \mathrm{~b}$ & $6 \mathrm{~b}$ & $6 \mathrm{~b}$ \\
\hline
\end{tabular}

Averages followed by the same letter in the column did not differ by the Scott-Knott test (1974) at 0.05 probability. The presented data were obtained from the original observations followed by the letters obtained from the comparison of averages with the transformation in arcsine $\sqrt{ }(x+0.5) / 100$.

TABLE 6. Infected seeds percentage during storage, number of dead insects of arena of free choice test and repellency index of aromatic plants used in seeds treatment

\begin{tabular}{lcccccccc}
\hline & \multicolumn{7}{c}{ Storage period (days) } \\
\cline { 2 - 8 } Treatments & \multicolumn{7}{c}{ Infested seed (\%) } & \multicolumn{7}{c}{ Number of dead insects } & \multicolumn{2}{c}{ Repelency index } \\
& 150 & $\mathbf{1 8 0}$ & $\mathbf{2 1 0}$ & $\mathbf{2 4 0}$ & $\mathbf{2 1 0}$ & $\mathbf{2 4 0}$ & $\mathbf{2 1 0}$ & $\mathbf{2 4 0}$ \\
\hline Rosemary & $0 \mathrm{a}$ & $0 \mathrm{a}$ & $0 \mathrm{a}$ & $0 \mathrm{a}$ & $8 \mathrm{a}$ & $4 \mathrm{a}$ & 0.99 & 0.57 \\
Cinnamon & $0 \mathrm{a}$ & $2 \mathrm{a}$ & $0 \mathrm{a}$ & $0 \mathrm{a}$ & $4 \mathrm{a}$ & $9 \mathrm{a}$ & 0.54 & 0.92 \\
Clove & $0 \mathrm{a}$ & $0 \mathrm{a}$ & $0 \mathrm{a}$ & $0 \mathrm{a}$ & $7 \mathrm{a}$ & $9 \mathrm{a}$ & 0.91 & 0.87 \\
Laurel & $0 \mathrm{a}$ & $1 \mathrm{a}$ & $1 \mathrm{a}$ & $2 \mathrm{a}$ & $7 \mathrm{a}$ & $7 \mathrm{a}$ & 0.88 & 0.90 \\
Basil & $0 \mathrm{a}$ & $0 \mathrm{a}$ & $0 \mathrm{a}$ & $1 \mathrm{a}$ & $3 \mathrm{a}$ & $10 \mathrm{a}$ & 0.61 & 1.02 \\
Diatomaceous Earth & $3 \mathrm{a}$ & $1 \mathrm{a}$ & $0 \mathrm{a}$ & $0 \mathrm{a}$ & $19 \mathrm{~b}$ & $14 \mathrm{~b}$ & 1.38 & 1.18 \\
Control & $0 \mathrm{a}$ & $1 \mathrm{a}$ & $2 \mathrm{a}$ & $1 \mathrm{a}$ & $9 \mathrm{a}$ & $9 \mathrm{a}$ & 1.00 & 1.00 \\
\hline
\end{tabular}

Averages followed by the same letter in the column did not differ by the Scott-Knott test (1974) at 0.05 probability.

treated. This avoids the insects entry, consequently, reduces the costs application of diatomaceous earth.

All tested aromatic plants had lower repellency indexes or very close to 1.0 indicating repellent or neutral effect. It was also observed that the repellency index of diatomaceous earth was higher than 1.0, so it would indicate that the diatomaceous earth would be attractive to insects. However, Mariano et al. (2006) defended that as diatomaceous earth adhered to insect epicuticle, it decreases the insects mobility in seed mass. Thus, diatomaceous earth retained insects and did not cause any attraction.

Cinnamon showed better repellency index (0.54) at 210 storage days. While, at 240 storage days, rosemary (0.57) showed better repellency index. The basil treatment showed a repellent effect until 210 days, but it was not observed in 240 days. So, it can be indicated a decrease of repellent effect. Basil also had no effect insecticide or repellent on $Z$. subfasciatus in beans as recorded by Girão Filho et al. (2014), different from that one observed in this work, which, after 210 storage days, still showed a repellent effect.

The clove treatment presented the same aswer as the trading insecticide Gastoxin ${ }^{\circledR}$ in studies by Paranhos et al. (2005). The authors recommended a $25 \mathrm{~g}$ dose of clove powder per kilo beans, further suggesting researches with lower doses. In the present study, $5 \mathrm{~g} \mathrm{~kg}^{-1}$ dose were used with similar results. Finally, the clove plant is well studied and has product patents for several uses, with the main substance studied eugenol, probably the active ingredient that causes repellency and insect mortality (Affonso et al., 2012).

Under the conditions that this trial was carried out, it can be concluded that treatments with rosemary, cinnamon, cloves and basil showed low percentage of infested seeds, indicating that their use can be possible as insecticides for Z. subfasciatus. The treatment with rosemary, cinnamon, clove, laurel and basil showed repellent 
effect at $5 \mathrm{~g} \mathrm{~kg}^{-1}$ seed. Whereas the storage period evaluated was long, when considering beans seeds, it can be concluded that the tested plants are promising for further research on their insecticidal effects. The treatments with aromatic tested plants did not affect water content, germination and one-hundred seed mass during 180 storage days. For storage periods after 90 days, diatomaceous earth increased abnormality symptoms in common-bean seedlings.

\section{REFERENCES}

AFFONSO, R.S. et al. Chemical and biological aspects of the essential oil of indian cloves. Revista Virtual de Química, v.4, n.2, p.146-161, 2012.

BRASIL. Ministério da Agricultura, Pecuária e Abastecimento. Regras para análise de sementes / Ministério da Agricultura, Pecuária e Abastecimento. Secretaria de Defesa Agropecuária. - Brasília: MAPA/ ACS, 2009. 399p.

BRASIL. Instrução Normativa ${ }^{\circ} 25$, de 20 de dezembro de 2005. Publicado na seção 1 do DOU n.243. Diário Oficial da República Federativa do Brasil, Poder Executivo, Brasilia, 2005. SEAB - Secretaria da Agricultura e Abastecimento. Padrões para produção e comercialização de sementes de feijão carioca. Disponível em: <http://www.agricultura.pr.gov.br/ arquivos/File/PDF/padroes_feijao.pdf>

COITINHO, R. L. B. de C., et al. Toxicity by fumigation, contact and ingestion of essential oils in Sitophilus zeamais Motschulsky, 1885 (Coleoptera: Curculionidae). Ciência e Agrotecnologia, v.35, n.1, p.172-178, 2011.

COSTA, A.R.T.; et al.Perry essential oil on the hyphae of some phytopathogenic fungi. Revista Brasileira de Plantas Meicinais, v.13, n.2, p.240-245, 2011.

ESTRELA, J.L.V.; et al. Toxicity of essential oils of Piper aduncum and Piper hispidinervum against Sitophilus zeamais. Pesquisa Agropecuária Brasileira, v.41, n.2, p.217-222, 2006.

FAZOLIN, M.; et al.Fumigation of maize for weevil control using Tanaecium nocturnum (Bignoniaceae). Pesquisa Agropecuária Brasileira, v.45, n.1, p.1-6, 2010.

FERREIRA, D.F. Sisvar: a computer statistical analysis system. Ciência e agrotecnologia, v.35, n.6, pp. 10391042. 2011.

GALBIATTI, J. A.; et al. Development of bean with the use of mineral fertilization and biofertilizer. Revista Engenharia Agrícola, v.31, n.1, p. 167-177, 2011.

GIRÃO FILHO, J.E.; et al. Repellency and insecticidal activity of plant powders onZabrotes subfasciatus (Boh.) on stored lima beans. Revista Brasileira de Plantas Medicinais, v.16, n.3, pp.499-504, 2014.

GUERRA, A.M.N.M.; et al. Insecticidal activity of medicinal plants on Callosobruchus maculatus (Coleoptera: Bruchidae). Revista Caatinga, v.22, n.1, p.146-150, 2009.

LAZZARI, F.N. Controle de Zabrotes subfasciatus e qualidade do feijão (Phaseolus vulgaris Linnaeus, 1753) tratado com terra de diatomácea. 2005. 79p Dissertação (Mestrado em Ciências Biológicas),
Curso de Pós-graduação em Ciências Biológicas, Universidade Federal do Paraná, Curitiba, PR.

MAIA, C. S.; PARENTE JÚNIOR, W. C. Citronela, aliada natural para repelir pernilongos. Norte Científico, v.3, n.1, p.1-7, 2008.

MARIANO, F. D.; et al. Utilização de terra de diatomácea como alternativa no controle de insetos em grãos de trigo armazenados. Revista Analytica, v. 24, n.1, p.60-64, 2006.

MWANGANGI, B.M.; MUTISYA, D.L. Performance of basil powder as insecticide against maize weevil, Sitopillus Zeamais (Coleoptera: Curculionidae). Discourse Journal of Agriculture and Food Sciences. v.1. n.11, p.196-201, 2013.

MAZZONETTO, F.; VENDRAMIN, J.D. Effect of powders from vegetal species on Acanthoscelides obtectus (Say) (Coleoptera: Bruchidae) in stored bean. Neotropical Entomology, v.32, n.1, p.145-149, 2003.

MIGLIORINI, P.; et al. Efficiency of vegetable extracts for the control of Diabrotica speciosa (Germar, 1824) (Coleoptera: Chrysomelidae), in the laboratory. Revista Biotemas, v.23, n.1, p.83-89, 2010.

MUNDO-CRIVELLI, S.R.; et al. Comparison between a homemade method for extraction of essential oil of rosemary and citronella with a hydrodistillation method. Revista Eletrônica Estácio Saúde, São José, v.3, n.2, p.31-34, 2014.

MWANGANGI, B.M.; MUTISYA, D.L. Performance of basil powder as insecticide against maize weevil, Sitopillus Zeamais (Coleoptera: Curculionidae). Discourse Journal of Agriculture and Food Sciences. v.1. n.11, p.196-201, 2013.

OLIVEIRA, J. V.; VENDRAMIN, J.D. Repellency of essencial oils and powders from plants on adults of Zabrotes subfasciatus (Boh.) (Coleoptera: Bruchidae) on bean seeds. Anuário da Sociedade de Entomologia do Brasil, v.28, n.1, p.549-555, 1999.

OOTANI, M.; et al. Use of essential oils in agriculture. Journal of Biotechnology and Biodiversity, v.4, n.1, p.162-175, 2013.

PACHECO, F.P.; NÓBREGA, L.H.P.; TONINI, M.; MAULI, M.M.; ROSA, D.M.; LORIN, H.E.F. Armazenamento de sementes de feijão tratadas com inseticida natural a base de pó de flores de cinamomo (Melia azedarach). In: CONGRESSO DA ACADEMIA TRINACIONAL DE CIÊNCIAS,v.1, n.3, 2008, Foz do Iguaçu. Anais... Jaboticabal:SBEA, 2008. CD ROM.

PARANHOS, B.A.G.; et al. Neem extract and Indian spice to control Zabrotes subfasciatus (Boheman) (Coleoptera: Bruchidae) in storage bean seeds. Colloquium Agrariae, v.1, n.1, p.1-7, 2005.

PINTO JÚNIOR, A.R.; et al. Bioactivity of essential oils of Brazilian sassafras and eucalyptus against lesser mealworm. Ciência Rural, v.40, n.3, p.637-643. 2010.

QUEIROGA, M. F. C.; et al. Oil aplication in the control of Zabrotes subfasciatus and in the germination of Phaseolus vulgaris. Revista Brasileira de Engenharia Agrícola e Ambiental, v.16, n.7, p.777-783, 2012.

SCOTT, A. J.; KNOTT, M. A. Cluster analysis method for grouping means in the analysis of variance. Biometrics, v.30, n.1, p.505-512, 1974.

SILVA, A.; et al. Seed phytate and protein content in beans depending on the application of basalt powder. Acta 
Scientiarum Agronomy, v.33, n.1, p. 147-152, 2011.

SOUZA, E.S.; BALDIN, E.L.L. Effect of vegetable powders and diatomaceous earth on biological aspects of Zabrotes subfasciatus (Boh., 1833) in stored beans. Arquivos do Instituto Biológico, v.76, n.3, p.401-
408, 2009.

TOLEDO, M.Z.; et al.Physiological quality and storage of bean seeds as affected by late side dressing nitrogen. Pesquisa Agropecuária Tropical, v.39, n.2, p.124133, 2009. 